\title{
Model Peningkatan Perilaku Caring pada Mahasiswa Jurusan Keperawatan Politeknik Kesehatan Kemenkes Pangkalpinang
}

\author{
Nurhayati \\ Prodi Keperawatan, Politeknik Kesehatan Kemenkes Pangkalpinang, Indonesia \\ Email: atybm27@gmail.com
}

\begin{abstract}
Caring Behavior Improvement Model for Students of Department of Nursing Polytechnic Health Ministry of Pangkalpinang. The purpose of this study was to establish the model and measurement of caring behavior in the students of Nursing Department Poltekkes Pangkalpinang. The method used is quantitative survey technique in stage I, an experiment by creating a book as a means of experimentation with the design Pretest-Posttest Group Single (The One Group Pretest posttest) for phase II. Followed by a qualitative phase III. A sample size of 69 students (i) level I and level II. The research found that. Variable Compassion (love) influence on the formation of Competention while variable concience (knowledge) and Commitment does not affect the establishment of Competention competence, while the overall variable Compassion (affection), concience (knowledge), Commitment and Competention (competencies) affect the establishment of Caring Behavior (Behavior caring).
\end{abstract}

Keywords: Behaviors, Caring behaviors, Student

\begin{abstract}
Abstrak: Model Peningkatan Perilaku Caring pada Mahasiswa Jurusan Keperawatan Politeknik Kesehatan Kemenkes Pangkalpinang. Tujuan penelitian ini adalah untuk menetapkan model dan alat ukur perilaku caring pada mahasiswa Jurusan Keperawatan Poltekkes Pangkalpinang. Metode penelitian yang digunakan adalah kuantitatif dengan teknik survei pada tahap I, eksperimen dengan membuat sebuah buku sebagai sarana eksperimen dengan desain Pratest-Postest Kelompok Tunggal (The One Group Pra-test Post-test) untuk tahap II. Dilanjutkan dengan kualitatif pada tahap III. Besar sampel sebanyak 69 mahasiswa (i) tingkat I dan tingkat II. Hasil penelitian ditemukan bahwa. Variabel Compassion (kasih sayang) berpengaruh terhadap pembentukan Competention (kompetensi), sedangkan variabel concience (pengetahuan) dan Commitment (komitmen) tidak berpengaruh terhadap pembentukan Competention kompetensi, sedangkan secara keseluruhan variabel Compassion (kasih sayang), concience (pengetahuan), Commitment (komitmen) dan Competention (kompetensi) berpengaruh terhadap pembentukan Caring Behavior (Perilaku caring).
\end{abstract}

Kata kunci: Perilaku, Perilaku caring, Mahasiswa

Agenda Sustainable Development Goals (SDGs) 2030 bidang kesehatan menetapkan tujuan untuk menjamin kehidupan yang sehat dan mendorong kesejahteraan bagi semua orang di segala usia (United Nations, 2016). Dalam praktek keperawatan manusia atau pasien merupakan suatu objek dari suatu pelayanan asuhan keperawatan dan care merupakan dasar atau landasan dalam memberikan asuhan keperawatan.

Keperawatan merupakan suatu bentuk pelayanan profesional yang mempunyai suatu paradigma atau model keperawatan yang meliputi empat komponen yaitu: manusia, kesehatan, lingkungan dan perawat itu sendiri. Perawat adalah suatu profesi yang mulia, karena memerlukan kesabaran dan ketenangan dalam melayani pasien yang sedang menderita sakit. Seorang perawat harus dapat melayani pasien dengan sepenuh hati. Sebagai seorang perawat harus dapat memahami masalah yang dihadapi oleh klien, selain itu seorang perawat dapat berpenampilan menarik. Untuk itu seorang perawat memerlukan kemampuan untuk memperhatikan orang lain, ketrampilan intelektual, teknikal dan interpersonal yang tercermin dalam perilaku caring atau kasih sayang (Strout, 2012).

Caring sangatlah penting untuk keperawatan. Caring adalah fokus pemersatu untuk praktik keperawatan. Perilaku caring juga sangat penting untuk tumbuh kembang, memperbaiki dan meningkatkan kondisi atau cara hidup manusia (Strout, 2012). 
Caring juga merupakan sikap peduli, menghormati dan menghargai orang lain, artinya memberi perhatian dan mempelajari kesukaankesukaan seseorang dan bagaimana seseorang berfikir dan bertindak. Memberikan asuhan (Caring) secara sederhana tidak hanya sebuah perasaan emosional atau tingkah laku sederhana, karena caring merupakan kepedulian untuk mencapai perawatan yang lebih baik, perilaku caring bertujuan dan berfungsi membangun struktur sosial, pandangan hidup dan nilai kultur setiap orang yg berbeda pada satu tempat (Strout, 2012). Maka kinerja perawat khususnya pada perilaku caring menjadi sangat penting dalam mempengaruhi kualitas pelayanan dan kepuasan pasien terutama di rumah sakit, dimana kualitas pelayanan menjadi penentu citra institusi pelayanan yang nantinya akan dapat meningkatkan kepuasan pasien dan mutu pelayanan (Strout, 2012). Di sisi lain, pengaruh layanan perawat terhadap kepuasan pasien (Suaib dkk, 2014), dan terhadap kesembuhan pasien sangat besar (Strout, 2012 dan Brilowski, 2005).

Karenanya diperlukan bukan saja kemampuan profesional yang memahami segala bentuk aktivitas keperawatan namun juga wajib memiliki perilaku caring bukan saja untuk memberikan layanan keperawatan yang berkualitas namun juga menghindarkan perawat dari penyalahgunaan dalam layanan kesehatan (Adrianus dkk., 2012).

Perilaku caring dalam berbagai kajian merupakan esensi dari keperawatan dan perilaku caring berhubungan dengan struktur pengetahuan dan teori yang dipelajarinya selama mengenyam pendidikan keperawatan dan dibentuk oleh cara perawat melaksanakan tugasnya serta kompleksitas nilai kepedulian yang tersedia (Favero dkk, 2012).

Terbentuknya perilaku caring dalam diri seorang perawat dimulai pada saat memutuskan menjadi perawat dan terukur dalam dedikasinya sebagai perawat dalam melaksanakan tugasnya dengan menggunakan seluruh pengetahuan profesional yang telah dipelajarinya dan besarnya norma-norma moral dan nilai-nilai yang dimilikinya (Krepia dkk, 2013).

Poltekkes Kemenkes Pangkalpinang sebagai institusi kesehatan yang mencetak calon perawat yang akan bekerja baik di Bangka Belitung pada khususnya dan Indonesia pada umumnya, juga harus dinilai sejak dini mahasiswa yang akan menerapkan asuhan keperawatan yang didapatkan di bangku kuliah dengan yang diterapkan di institusi temapt mereka praktik maupun bekerja nantinya.
Mengacu kepada uraian di atas maka dipandang penting untuk membentuk kerangka peningkatan perilaku caring kepada mahasiswa keperawatan dengan menemukan strategi dasar yang mampu membentuk karakter caring yang bermanfaat bagi mahasiswa dalam melaksanakan tugasnya sebagai perawat di masa depan, dalam sebuah kajian berjudul: Model Peningkatan Perilaku Caring Pada Mahasiswa Jurusan Keperawatan Poltekkes Pangkalpinang.

Tujuan penelitian ini adalah untuk menetapkan model dan alat ukur perilaku caring pada mahasiswa Jurusan Keperawatan Poltekkes Pangkalpinang.

\section{METODE}

Metode penelitian yang digunakan adalah kuantitatif dengan teknik survai pada tahap I, eksperimen dengan membuat sebuah buku sebagai sarana eksperimen dengan desain PratestPostest Kelompok Tunggal (The One Group Pratest Post-test) untuk tahap II. Eksperimen dilakukan pada satu kelompok saja tanpa kelompok pembanding dengan mengadakan pratest kemudian setelah diberikan perlakuan yaitu penggunaan buku panduan caring yang disusun dilakukan pengukuran (post-test) untuk mengetahui akibat dari perlakukan itu, sehingga besarnya efek dari eksperimen dapat diketahui dengan pasti. Pengujian perilaku caring ini dipantau oleh perceptor pada saat mahasiswa praktek di lahan. Selanjutnya pada tahap III menggunakan teknik kualitatif yaitu dengan melakukan wawancara pada mahasiswa, pengelola Prodi dan Stakeholder dalam hal ini perwakilan preceptor di rumah sakit.

Populasi dalam penelitian ini adalah seluruh mahasiswa Poltekkes Pangkal Pinang Tingkat I dan Tingkat II, sebanyak 69 orang, dengan rincian 30 mahasiswa tingkat I dan 39 mahasiswa Tingkat II. Sampel dalam penelitian ini adalah seluruh mahasiswa tingkat I dan tingkat II dengan jumlah 69 orang.

\section{HASIL}

\section{Pengujian Faktor Determinan}

Melalui uji regresi diperoleh informasi mengenai pengaruh dari faktor determinan berupa besarnya pengaruh variabel jenis kelamin, tingkatan mahasiswa, minat, komitmen, kurikulum, dan pengetahuan awal terhadap perilaku caring mahasiswa, mengacu pada: 
Tabel 1. Uji Faktor Determinan

\begin{tabular}{ccccc}
\hline Model & $\mathbf{R}$ & $\begin{array}{c}\boldsymbol{R} \\
\text { Square }\end{array}$ & $\begin{array}{c}\text { Adjusted } \\
\text { R Square }\end{array}$ & $\begin{array}{c}\text { Std.Error } \\
\text { of The } \\
\text { Estimate }\end{array}$ \\
\hline 1 & 0,772 & 0,596 & 0,577 & 5,12121 \\
\hline
\end{tabular}

Angka koefisien determinasi sebesar 0,596 atau $59,60 \%$ menunjukkan bahwa sebesar $59,60 \%$ bentukan perilaku caring mahasiswa dapat dijelaskan menggunakan variabel jenis kelamin, tingkatan mahasiswa, minat, komitmen, kurikulum, dan pengetahuan awal, sedangkan sisanya yaitu $40,40 \%$ dapat dijelaskan oleh faktor penyebab lainnya.

Dengan kata lain bahwa besarnya pengaruh variabel jenis kelamin, tingkatan mahasiswa, minat, komitmen, kurikulum, dan pengetahuan awal terhadap perilaku caring mahasiswa adalah sebesar 59,60\%.

Besar standar error of estimate (SEE) sebesar 5,12121 menjelaskan bahwa keberadaan jenis kelamin, tingkatan mahasiswa, minat, Komitmen, kurikulum, dan pengetahuan awal dapat menjadi predictor terhadap perilaku caring mahasiswa.

\section{Pengujian Model Perilaku Caring}

Berdasarkan data diperoleh informasi bahwa umumnya perilaku caring mahasiswa dalam penelitian ini berada pada kategori baik, meskipun terdapat perbedaan antara perilaku caring antara mahasiswa tingkat 1 dengan mahasiswa tingkat 2. Diketahui bahwa pada mahasiswa tingkat 1 kriteria perilaku caring berada pada kategori baik, namun hanya pada interval $63,07 \%$ sedangkan pada mahasiswa tingkat 2 sebesar $65,00 \%$.

Berdasarkan data diketahui bahwa terdapat tujuh aspek perilaku caring yang belum optimal berdasarkan Daftar dimensi caring (Caring Dimensions Inventory; CDI) yang didesain oleh Watson dan Lea (1997), sebagai berikut.
Tabel 2 Perilaku Caring Mahasiswa

\begin{tabular}{|c|c|c|c|}
\hline No. & Perilaku caring & $\%$ & Kategori \\
\hline CDI 1. & Membantu klien dalam ADL; & 59,06 & $\begin{array}{l}\text { Kurang } \\
\text { baik }\end{array}$ \\
\hline CDI 2. & $\begin{array}{l}\text { Membuat catatan keperawatan } \\
\text { mengenai klien; }\end{array}$ & 59,78 & $\begin{array}{l}\text { Kurang } \\
\text { baik }\end{array}$ \\
\hline CDI 3. & $\begin{array}{l}\text { Merasa bersalah /menyesal } \\
\text { kepada klien; }\end{array}$ & 63,41 & Baik \\
\hline CDI 4. & $\begin{array}{l}\text { Memberikan pengetahuan } \\
\text { kepada klien sebagai individu; }\end{array}$ & 60,14 & $\begin{array}{l}\text { Kurang } \\
\text { baik }\end{array}$ \\
\hline CDI 5. & Menjelaskan prosedur klinik; & 61,59 & $\begin{array}{l}\text { Kurang } \\
\text { baik }\end{array}$ \\
\hline CDI 6. & $\begin{array}{l}\text { Berpakaian rapi ketika bekerja } \\
\text { dengan klien; }\end{array}$ & 63,77 & Baik \\
\hline CDI 7. & Duduk dengan klien; & 65,58 & Baik \\
\hline CDI 8. & $\begin{array}{l}\text { Mengidentifikasi gaya hidup } \\
\text { klien; }\end{array}$ & 61,23 & $\begin{array}{l}\text { Kurang } \\
\text { baik }\end{array}$ \\
\hline CDI 9. & $\begin{array}{l}\text { Melaporkan kondisi klien } \\
\text { kepada perawat senior; }\end{array}$ & 64,86 & Baik \\
\hline CDI 10. & $\begin{array}{l}\text { Bersama klien selama prosedur } \\
\text { klinik; }\end{array}$ & 62,32 & Baik \\
\hline CDI 11. & Bersikap manis dengan klien; & 65,58 & Baik \\
\hline CDI 12. & $\begin{array}{l}\text { Mengorganisasi pekerjaan } \\
\text { dengan perawat lain untuk } \\
\text { klien; }\end{array}$ & 73,55 & Baik \\
\hline CDI 13. & Mendengarkan klien; & 63,41 & Baik \\
\hline CDI 14. & $\begin{array}{l}\text { Konsultasi dengan dokter } \\
\text { mengenai klien; }\end{array}$ & 64,49 & Baik \\
\hline CDI 15. & $\begin{array}{l}\text { Menganjurkan klien mengenai } \\
\text { aspek self care; }\end{array}$ & 63,04 & Baik \\
\hline CDI 16. & $\begin{array}{l}\text { Melakukan sharing mengenai } \\
\text { masalah pribadi dengan klien; }\end{array}$ & 59,78 & $\begin{array}{l}\text { Kurang } \\
\text { baik }\end{array}$ \\
\hline CDI 17. & $\begin{array}{l}\text { Memberikan informasi } \\
\text { mengenai klien; }\end{array}$ & 75,72 & Baik \\
\hline CDI 18. & Mengukur tanda vital klien; & 63,41 & Baik \\
\hline CDI 19. & $\begin{array}{l}\text { Menempatkan kebutuhan klien } \\
\text { sebelum kebutuhan pribadi; }\end{array}$ & 64,13 & Baik \\
\hline CDI 20. & $\begin{array}{l}\text { Bersikap kompeten dalam } \\
\text { prosedur klinik; }\end{array}$ & 65,94 & Baik \\
\hline CDI 21. & $\begin{array}{l}\text { Melibatkan klien dalam } \\
\text { perawatan; }\end{array}$ & 63,04 & Baik \\
\hline CDI 22. & $\begin{array}{l}\text { Memberikan jaminan mengenai } \\
\text { prosedur klinik; }\end{array}$ & 70,29 & Baik \\
\hline CDI 23. & $\begin{array}{l}\text { Memberikan privacy kepada } \\
\text { klien; }\end{array}$ & 63,77 & Baik \\
\hline CDI 24. & Bersikap gembira dengan klien; & 61,59 & $\begin{array}{l}\text { Kurang } \\
\text { baik }\end{array}$ \\
\hline CDI 25. & $\begin{array}{l}\text { Mengobservasi efek medikasi } \\
\text { kepada klien. }\end{array}$ & 64,49 & Baik \\
\hline
\end{tabular}

\section{Pembentukan Model}

Berdasarkan analisis diketahui bahwa Pengukuran Kompetensi sebagai variabel independen karena asumsi bahwa variabel 
determinan kompetensi dan pengetahuan merupakan variabel determinan yang memiliki besaran pengaruh yang besar, sehingga pengukuran pertama menjadikan kompetensi (Competence) sebagai variabel dependen, sedangkan variebel Compassion (X1), Concience (X2) dan Commitment (X3) menjadi variabel independen.

Angka koefisien determinasi sebesar 0,470 atau $47,00 \%$ menunjukkan bahwa sebesar $47,00 \%$ bentukan kompetensi caring mahasiswa dapat dijelaskan menggunakan variabel Compassion, Concience dan Commitment, sedangkan sisanya yaitu $53,00 \%$ dapat dijelaskan oleh faktor penyebab lainnya. Dengan kata lain bahwa besarnya pengaruh variabel Compassion, Concience dan Commitment terhadap kompetensi caring mahasiswa adalah sebesar 53,00\%.

Besar standar error of estimate (SEE) sebesar 4,33163 jika menjelaskan bahwa keberadaan Compassion, Concience dan Commitment dapat menjadi predictor terhadap kompetensi caring mahasiswa. Karena angka probabilitas Sig 0,036<0,05 maka model regresi ini layak untuk digunakan dalam memprediksi perilaku caring.

Uji kedua menggunakan parameter variabel behavior (Y2) sebagai variabel dependent, sedangkan variabel Compassion (X1), Concience (X2), Commitment (X3) dan (X) Competence menjadi variabel independen. Angka koefisien determinasi sebesar 1,000 atau 100,0\% menunjukkan bahwa sebesar $100 \%$ bentukan perilaku caring mahasiswa dalam penelitian ini dapat dijelaskan menggunakan variabel Compassion, Concience, Commitment dan Competence. Dengan kata lain bahwa besarnya pengaruh variabel Compassion, Concience, Commitment dan Competence terhadap perilaku caring mahasiswa adalah sebesar $100 \%$.

Besar standar error of estimate (SEE) sebesar 0,0000 jika menjelaskan bahwa keberadaan Compassion, Concience, Commitment dan Competence dapat menjadi predictor terhadap kompetensi perilaku caring mahasiswa.

\section{PEMBAHASAN}

\section{Pengujian Faktor Determinan}

Berdasarkan sejumlah teori dan analisis data maka diketahui bahwa faktor determinan yang memberikan pengaruh dalam pembentukan perilaku caring pada mahasiswa terdiri atas variabel; (1) jenis kelamin, (2) tingkatan mahasiswa, (3) minat mahasiswa menjadi perawat, (4) komitmen mahasiswa dalam tugas keperawatan, (5) kurikulum yang digunakan dalam pembentukan perilaku caring, dan (6) Pengetahuan awal yang dimiliki mahasiswa.

Perilaku caring (caring behavior) dibangun oleh tiga komponen penting, yaitu; Kasih sayang (Compassion); Kepercayaan diri (Confidence), dan; Komitmen (Commitment). Ketiga aspek ini merupakan aspek performance dari perilaku caring, yang pada dasarnya dibentuk oleh dua komponen yaitu; Kompetensi (Competence) dan standar moral (Concience).

Diketahui bahwa pada umumnya mahasiswa tingkat 2 yang telah melampaui proses perkuliahan dengan sejumlah penerimaan materi perkualiahan nampaknya telah memiliki kesadaran dan kecintaan terhadap profesi sebagai perawat, sehingga terlihat bahwa pada umumnya mahasiswa tingkat 2 lebih memiliki perilaku caring yang lebih baik dibanding mahasiswa tingkat pertama.

Di sisi lain, pengalaman dinas dan praktek pada rumah sakit ataupun puskesmas yang memberikan kesempatan kepada mahasiswa untuk mepraktekkan pengetahuan dan keterampilan yang telah dipelajarinya dalam perkuliahan memberikan efek penguasaan kompetensi keperawatan yang lebih besar pada mahasiswa tingkat 2 dibanding mahasiswa tingkat pertama.

Data lain menunjukkan bahwa mahasiswa perempuan cenderung memiliki perilaku caring yang lebih baik dibanding mahasiswa laki-laki. Berdasarkan data yang dikumpulkan bahwa umumnya mahasiswa perawat laki-laki memiliki perilaku caring lebih rendah, namun memiliki peningkatan manakala mahasiswa laki-laki telah berada pada tingkat 2 . Meski demikian variabel jenis kelamin mahasiswa pada penghitungan uji regresi didapatkan Dengan prasyarat jika $\mathrm{t}_{\text {hitung }}<\mathrm{t}_{\text {tabel }}\left(\alpha\right.$ 0,10:n-1) maka $\mathrm{H}_{0}$ diterima dan $\mathrm{H}_{1}$ ditolak, tetapi jika $t_{\text {hitung }}>t_{\text {tabel }}(\alpha 0,10: n-1)$ maka $\mathrm{H}_{0}$ ditolak dan $\mathrm{H}_{1}$ diterima. Koefisien regresi pada variabel jenis kelamin adalah $0,114<1,667$ yang berarti bahwa $\mathrm{H}_{0}$ diterima dan $\mathrm{H}_{1}$ ditolak, atau dengan kata lain bahwa pengaruh variabel jenis kelamin adalah tidak signifikan memberikan pengaruh terhadap perilaku, dibanding dengan pengaruh signifikan yang dimiliki oleh tingkatan mahasiswa.

Hal ini menjelaskan bahwa selama melalui proses perkuliahan yang baik serta memberikan ruang untuk melakukan praktek secara nyata di rumah sakit atau puskesmas guna mengimplementasikan ilmu dan keterampilan yang dimiliki mahasiswa baik laki-laki maupun 
perempuan tetaplah sama perlakuan yang diberikan ke pasien maupun perlakuan yang didapatkan di ruang kelas.

Hal ini menjelaskan kembali bahwa konsepsi konvensional yang menyatakan bahwa caring dalam tugas keperawatan sebagai fenomena universal yang menyatakan bahwa perempuan bertugas merawat anak-anak, sehingga keterlibatan perempuan dalam hal perawatan di semua budaya menghasilkan ekspresi bahwa perilaku caring adalah ekspresi ketulusan jiwa dalam memberikan perawatan sesuai konteks filosofis yang dominan berlangsung pada era masing-masing (Sukesi, 2013), pada saat ini telah mengalami pergeseran dimana kehadiran pendidikan keperawatan memberikan peran yang jelas sama kepada perempuan dan laki-laki.

Pendidikan keperawatan yang berlangsung dengan baik akan membangun minat, komitmen dan kompetensi bagi mahasiswa calon perawat. Bahwa meskipun pada awalnya mahasiswa ada yang tidak mampu mengikuti perkuliahan ataupun tidak memiliki latar belakang keluarga sebagai perawatan yang mungkin akan memberikan motivasi namun pendidikan keperawatan yang diperoleh baik dalam perkuliahan maupun dalam praktek akan mampu menumbuhkan membangun minat, komitmen dan kompetensi mahasiswa sebagai perawat yang profesional.

Berdasarkan data yang dianalisis menunjukkan bahwa variabel minat, komitmen dan kompetensi pada mahasiswa berpengaruh secara signifikan terhadap perilaku caring mahasiswa dalam implementasi mereka di rumah sakit atau dalam kehidupan sehari-hari. Hal ini tentunya sesuai dengan teori yang menyatakan bahwa perkembangan dunia keperawatan yang telah mengadopsi teknologi mengarahkan perilaku caring para perawat bukan saja kepada ketulusan jiwa dalam melakukan perawatan kepada pasien namun juga merupakan kemampuan untuk berdedikasi bagi orang lain, melakukan pengawasan dengan waspada, menunjukkan perhatian, perasaan empati pada orang lain dan perasaan cinta atau menyayangi (Strout, 2012).

Dukungan teori tersebut tampak pada data yang menunjukkan bahwa komitmen mahasiswa keperawatan terhadap profesi sebagai perawat memberikan pengaruh signifikan terhadap perilaku caring, yang nampak pada komitmen mereka dalam memberikan empati dalam pelaksanaan prakteknya. Ketulusan dalam melayani dan komitmen mengikuti prosedur keperawatan telah dilaksanakan dengan baik oleh mahasiswa.

Meskipun data menunjukkan bahwa kurikulum atau muatan perilaku caring yang diinginkan belumlah sesuai sehingga nampak dalam analisis bahwa variabel kurikulum tidak signifikan memberikan pengaruh terhadap perilaku caring. Berbagai asumsi tentunya ditunjukkan bahwa konsepsi caring selanjutnya secara parsial dipelajari oleh mahasiswa baik melalui pengalaman maupun dalam menarik makna dalam perkuliahan mereka. Proses penarikan makna caring nampak dalam signifikannya pegaruh variabel pengetahuan mahasiswa terhadap perilaku caring mereka.

\section{Pengujian Model Perilaku Caring}

Pada pengujian ini terdiri atas penyusunan materi integrasi dan ujicoba materi integrasi yang disusun dalam sebuah buku saku pedoman Perilaku Caring. Setelah melalui tahapan diskusi dan pengamatan maka ditentukan susunan buku pedoman sebagai berikut. Bab 1. Pengantar, Bab 2. Pengertian Caring, Bab 3. Perilaku Caring, $\mathrm{Bab}$ 4. Caring Terhadap Pasien, Bab 5. Komunikasi dengan Caring, Bab 6. Pengembangan Caring

Selanjutnya buku Panduan Caring bagi mahasiswa tersebut diberikan kepada mahasiswa untuk dipelajari dan melakukan penyesuaian pada tahapan mana dalam mata kuliah mereka yang tengah diikuti dan pada bagian dimana mereka melakukan praktek dan telah melakukan praktek perilaku caring.

Hasil observasi yang dilakukan oleh perceptor dan pengisian kueioner menunjukkan data bahwa perilaku caring yang dilakukan mahasiswa umumnya adalah perilaku yang sesuai dengan prosedur tindakan keperawatan yaitu:

1. Memberikan informasi mengenai klien;

2. Mengorganisasi pekerjaan dengan perawat lain untuk klien;

3. Memberikan jaminan mengenai prosedur klinik;

4. Bersikap kompeten dalam prosedur klinik;

5. Duduk dengan klien;

6. Bersikap manis dengan klien;

7. Melaporkan kondisi klien kepada perawat senior;

8. Konsultasi dengan dokter mengenai klien;

9. Mengobservasi efek medikasi kepada klien.

10.Menempatkan kebutuhan klien sebelum kebutuhan pribadi;

11.Berpakaian rapi ketika bekerja dengan klien;

12.Memberikan privacy kepada klien;

13.Merasa bersalah /menyesal kepada klien; 
14. Mendengarkan klien;

15.Mengukur tanda vital klien;

16.Menganjurkan klien mengenai aspek self care;

17.Melibatkan klien dalam perawatan;

18. Bersama klien selama prosedur klinik;

Sedangkan aspek perilaku caring yang masih lemah meliputi perilaku caring yang terimplementasi secara luas dalam seluruh praktek keperawatan yang dilakukan serta proses kasih sayang (compassion) dan (empati) concience antara lain; Menjelaskan prosedur klinik; Bersikap gembira dengan klien; Mengidentifikasi gaya hidup klien; Memberikan pengetahuan kepada klien sebagai individu.

Aspek kompetensi lainnya yang paling lemah adalah perilaku caring yang mengimplementasikan kerja keperawatan profesional yang lebih luas, meliputi; Membuat catatan keperawatan mengenai klien; Melakukan sharing mengenai masalah pribadi dengan klien; Membantu klien dalam ADL.

\section{Pembentukan Model}

Pada pengujian tahap III, adalah tahapan evaluasi pelaksanaan integrasi dengan menggunakan pedoman wawancara untuk menelusuri model pengembangan yang dapat dilakukan. Pengujian terhadap variabel Compassion (kasih sayang) berupa kepekaan terhadap kesulitan dan kepedihan orang lain dapat berupa membantu seseorang untuk tetap bertahan, memberikan kesempatan untuk berbagi, dan memberi ruang bagi orang lain untuk berbagi perasaan, serta memberikan dukungan secara penuh, nampaknya memberikan pengaruh terhadap pembentukan perilaku untuk melakukan kerja Commitment adalah melakukan tugas secara konsekuen dan berkualitas terhadap tugas, orang, serta karier perawat yang dipilih.

Meski demikian variabel Competence yaitu kemampuan untuk memiliki ilmu pengetahuan, keterampilan, pengalaman, energi dan motivasi sebagai rasa tanggung jawab terhadap profesi serta Confidence atau kepercayaan diri berupa suatu keadaan untuk memelihara hubungan antar manusia dengan penuh percaya diri, secara statistik tidak memberikan pengaruh terhadap kompetensi mahasiswa secara langsung.

Berdasarkan wawancara dengan mahasiswa (P1:Perempuan) diketahui bahwa pada umumnya kepekaan terhadap kesulitan dan kepedihan pasien yang terwujud dalam tindakan membantu seseorang untuk tetap bertahan, memberikan kesempatan untuk berbagi, dan memberi ruang bagi orang lain untuk berbagi perasaan, umumnya lahir dari rutinitas pelaksanaan praktek, karena dalam perkuliahan pembahasan mengenai kepekaan itu sendiri meskipun ada namun hanya muncul secara implisit dalam uraian dari dosen.

Dalam berbagai diskusi sering pula muncul kasus yang didiskusikan bersama oleh mahasiswa dan dosen, dan memberikan kesempatan kepada mahasiswa untuk menumpahkan perasaan dan menumbuhkan empatinya terhadap profesi keperawatan yang dijalaninya, meskipun disadari bahwa perkuliahan lebih banyak mengungkap persoalan teknis tindakan keperawatan.

Responden (P1:Perempuan) menyatakan bahwa pelayanan dalam praktek di rumah sakit sangat dibutuhkan karena meskipun pengetahuan mahasiswa telah baik, namun kenyataannya dalam praktek perilaku caring sendiri telah dilakukan sesuai indikator yang dipelajari dalam buku panduan, meskipun pada awalnya perilaku caring dipandang belum dilakukan, sebagai contoh implementasi dalam mata kuliah KMB perlu menegakkan asuhan keperawatan yang memerlukan perilaku dari perawat atau (mahasiswa*). Perilaku caring yang dilakukan oleh mahasiswa masih bergantung kepada sifat dari pasien itu sendiri (apakah pasiennya terbuka/mau mengungkapkan apa yang dirasakannya selama dirawat dan tidak berdiam diri).

Menurut wawancara dengan mahasiwa (L1:Laki-laki) bahwa umumnya kepercayaan diri mahasiswa dalam berdiskusi dan melakukan tindakan saat melaksanakan praktek tumbuh karena menguasai hafalan-hafalan tindakan yang ada dalam teks book, serta catatan perkuliahan, namun masih sedikit dosen yang menyisipkan materi bagaimana seorang mahasiswa menumbuhkan kepercayaan diri dalam melaksanakan tindakan. Mahasiswa masih sering mendapat penolakan dari keluarga dan pasien karena kepercayaan pasien kepada perawat (mahasiswa*) yang melayani. Menurut responden, hal ini terjadi karena pandangan pasien yang belum terbentuk akibat perilaku caring perawat (mahasiswa) yang belum optimal.

(L1:Laki-laki) menyadari bahwa seorang perawat wajib memiliki standar moral yang tumbuh dari sistem nilai humanistik yang menghargai dan mau peduli terhadap kesejahteraan atau kesehatan pasiennya. Namun aspek utama yang perlu dibangun adalah mahasiswa harus terlebih dahulu melakukan perubahan terhadap perilaku dirinya.

Oleh karena itu, kompetensi atau penguasaan tidaklah terbangun serta merta dari kepedulian dan rasa cinta pada profesi saja 
namun wajib melalui sebuah proses pendidikan keperawatan yang secara terstruktur membangun kasih saya, empati, pengetahuan caring itu sendiri secara eksplisit dalam perkulaiahn dalam setiap mata kuliah yang diajarkan.

Analisis data kedua menunjukkan bahwa perilaku caring terbangun penuh secara bersamasama dari aspek: Compassion (kasih sayang) atau kepekaan terhadap kesulitan dan kepedihan orang lain, Competence (kemampuan) atau pengetahuan, keterampilan, pengalaman, energi dan motivasi sebagai rasa tanggung jawab terhadap profesi, Concience (suara hati) berupa standar moral yang tumbuh dari sistem nilai humanistik altruisti dan Commitment dalam tugas secara konsekuen dan berkualitas terhadap tugas, orang, karier yang dipilih. Secara bersama-sama variabel tersebut haruslah dimiliki dan dijalankan oleh seorang mahasiswa agar mampu memiliki perilaku caring yang baik.

Hal ini sesuai dengan teori yang menegaskan bahwa Caring haruslah didefinisikan sebagai tindakan yang bertujuan memberikan asuhan fisik dan memperhatikan emosi sambil meningkatkan rasa aman dan keselamatan pasien (Favero, 2012) karenanya Sikap Caring harus diberikan melalui kejujuran, kepercayaan, dan niat baik secara sekaligus.

Hal ini sejalan dengan wawancara dengan mahasiswa (P2:perempuan) yang menyatakan bahwa sebaiknya perkuliahan memasukkan materi caring sesuai dengan buku Pedoman yang dikembangkan oleh peneliti, namun pada tahap awal sebaiknya disisipkan (diintegrasikan *) dalam setiap mata kuliah.

Responden (P3:peremuan) menyatakan bahwa pendekatan dalam melakukan asuhan keperawatan harus murni dilakukan secara tulus untuk membantu proses penyembuhan pasien, bukan untuk membuat laporan asuhan keperawatan. Meskipun responden menyatakan bahwa umumnya mereka baru mengetahui bahwa tindakan tersebut adalah tindakan caring berdasarkan buku panduan caring yang telah dibacanya.

Wawancara dengan mahasiswa (L2:Lakilaki) mengharapkan agar lebih banyak contoh dalam buku panduan, meski mengharapkan lebih banyak pengertian yang detail dalam aspek keberanian, aspek komunikasi verbal sehingga keberanian diperlukan yang baik dalam mengimplementasikan kemampuannya.

Responden (L3:Laki-laki) menyatakan bahwa rasa percaya diri perlu dibangun dengan mengetahui ilmu keperawatan yang baik serta terampil melakukannya, sehingga kepercayaan keluarga dan pasien itu sendiri akan tumbuh.
Diskusi dengan tim dosen pengampu mata kuliah menegaskan pentingnya buku panduan Caring segera dihadirkan menjadi pelengkap perkuliahan, disamping menjadi panduan bagi mahasiswa juga menjadi referensi pendukung bagi dosen mata kuliah dalam memberikan mata kuliah sehingga baik secara integratis ataupun sebagai bahan guidance, maka panduan caring dapat digunakan secara optimal.

Adapun alat ukur yang dapat digunakan dalam mengukur sejauh mana perilaku caring telah dapat hadir dalam diri seorang perawat pada tahapan awal adalah menggunakan Daftar Dimensi Caring (Caring Dimensions Inventory; CDI) yang didesain oleh Watson dan Lea (1997) merupakan instrumen yang dikembangkan untuk meneliti perilaku perawat (perilaku caring), dan pada tahapan selanjutnya adalah Menggunakan struktur dari perilaku caring (Swanson, 1993).

Dalam pengembangannya, mahasiswa akan diantar pada sebuah model pengembangan perilaku caring secara individual dengan tahapan dimana seorang mahasiswa dianggap telah memiliki perilaku caring apabila secara bertahap telah mampu mengantar/mendampingi/merawat pasiennya sampai pasiennya mampu melakukan perawatan yang mandiri.

\section{SIMPULAN}

1. Faktor determinan yang bekerja mempengaruhi pembentukan perilaku caring pada mahasiswa adalah komitmen mahasiswa sebagai mahasiswa calon tenaga perawat, pengetahuan keperawatan, minat mahasiswa sebagai perawat, dan tingkatan mahasiswa, serta pengaruh tidak langsung dari variabel jenis kelamin dan kurikulum perkuliahan.

2. Buku pedoman Caring disusun dalam struktur sebagai berikut; Bab 1. Pengantar; Bab 2. Pengertian Caring; Bab 3. Perilaku Caring; Bab 4. Caring Terhadap Pasien; Bab 5. Komunikasi dengan Caring; dan Bab 6. Pengembangan Caring.

3. Variabel Variabel Compassion (kasih sayang) berpengaruh terhadap pembentukan Competention kompetensi, sedangkan variabel concience (pengetahuan) dan Commitment (komitmen) tidak berpengaruh terhadap pembentukan Competention kompetensi, sedangkan secara keseluruhan variabel Compassion (kasih sayang), concience (pengetahuan), Commitment (komitmen) dan Competention (kompetensi) berpengaruh 
terhadap pembentukan Caring Behavior (Perilaku caring).

\section{SARAN}

1. Sebaiknya Poltekkes Kemenkes Pangkalpinang atau Poltekkes lain pencetak calon tenaga perawat perlu satu mata kuliah khusus yang membahas mengenai caring.

\section{DAFTAR PUSTAKA}

Adrianus Jelmer Brüggemann, Barbro Wijma and Katarina Swahnberg. 2012. Abuse in health care: a concept analysis. Scandinavian Journal of Caring Sciences, Volume 26 No. 1; 123-132.

Favero, Luciane, Moria Marlene Freitag Pagluca dan Maria Ibeiro Lacerda. 2012. Transpersonal Caring in Nursing: an Analysis Groundend in a Conceptual Model. www.scielo.br. Diakses tanggal 10 Maret 2016.

Krepia, Despina Sapountzi, Maria Lavdaniti, Maria Psychogiou dan Maria Tsiligiri, Savvas Karassavidis, Sara Sarpeta. 2013. The Concept of Care as Perceived by Greek Nursing Student: a Focus Group Aproach. International Journal of Caring Sciences, Volume 6, Issues 3.

Suaib, Indar dan Nurhaedar Jafar. 2014. Pengaruh Kualitas Pelayanan terhadap Pasien di Ruang Rawat Inap RSUD Syech Yusuf Kabupaten Gowa. E-Journal Program Pascasarjana Univeritas Hasanuddin. Fakultas Kesehatan Masyarakat Universitas, Makassar. http://pasca.unhas.ac.id/jurnal/files/418ef3 c5a30c8713e8eb916d77829c11.pdf
2. Sebaiknya Poltekkes Pangkalpinang menigkatkan perilaku caring mahasiswa sejak dini dengan menggunakan pendekatan psikologis yaitu melalui supervisi dan pembinaan serta role model yang baik dari pembimbing akademik dan perceptor.

3. Sebaiknya peneliti selanjutnya menambahkan metode observasi dan wawancara lebih mendalam untuk memperoleh hasil penelitian yang lebih mendalam mengenai model perilaku caring pada mahasiswa.

Sukesi, N. 2013. Upaya Peningkatan Caring Perawat Terhadap Kepuasan Pasien Diruang Rawat Inap RS Permata Medika Semarang. Jurnal Manajemen Keperawatan, 1(1). https://www.neliti.com/publications/11162 8/upaya-peningkatan-caring-perawatterhadap-kepuasan-pasien-diruang-rawatinap-rs. Diakses 10 Maret 2016

Strout, K. 2012. Wellness promotion and the Institute of Medicine's Future of Nursing Report: are nurses read y? Holistic Nursing Practice Volume 26 (3):129-36.

Swanson, Kristen.M. 1993. Nursing as Informed Caring for the Well-Being of Others. Journal of Nursing Scholarship Volume 25 No. 3.

United Nations. 2016. Transforming our world: the 2030 Agenda for Sustainable Development. https://sustainabledevelopment.un.org/pos t2015/. Diakses 10 Maret 2016.

Watson, Roger, Amandah Lea. 1997. The caring dimensions inventory (CDI): content validity, reliability and scaling. Journal of Advanced Nursing, 1997, 25,87-94. 